\title{
有限要素法による船体振動の付加質量抢よび 付加慣性モーメントの計算
}

\author{
正員 松 浦 義 一* \\ 正員川上肇**
}

Calculation of Added Virtual Mass and Added Virtual Mass Moment of Inertia of Ship

Hull Vibration by the Finite Element Method

By Yoshikazu Matsuura, Member

Hajime Kawakami, Member

Summary

The added virtual mass and the added virtual mass moment of inertia induced by the vibration of a ship are defined as the equivalent mass and the equivalent mass moment of inertia deduced from the effects of water surrounding a vibrating ship. These equivalent mass and the equivalent mass moment of inertia can be estimated either from the inertia force (or moment) concept or from the kinetic energy concept as long as the ideal fluid is concerned, and the solution of the Laplace's differential equation is required in both cases.

This paper, dealing with the problem by the use of the inertia force(or moment)concept, shows that the so-called"finite element method"can be applied, with the aid of a high speed digital computer, to obtain the approximate solution of the Laplace's differential equation with any arbitrary boundary condition. In order to examine the accuracy of this method, the inertia coefficients $C_{V}$, $C_{H}$ and $C_{T}$ of vertical, horizontal and rotational vibrations of bars of circular and rectangular cross section are computed first by this method. Then, as an application of this method, the effects on the inertia coefficients of the restricted water and of the bilgekeel are shown numerically.

\section{1 緒言}

船体振動や船体連動の付加質量を理論的に求める場合，ある境界条件の下でラプラスの方程式を解く必要があ る。ラプラスの方程式の解は複素ポテンシャル, 等甶写像等を用いて解析的に求めるのが普通である。特定の形 状の境界をもつ場合，たとえば 2 次元では円，矩形，Lewis form，3 次元では回転楕円体等についての解は解析 的な方法によつて解かれている。しかし任意形状の境界をもつ場合にはラプラスの方程式を解析的に解くことは 困難である。

最近電子計算機の発達に伴つて弾望性力学や構造力学の分野で有限要素法あるいはマトリックス法と呼ばれる 新しい構造解析法が開発され急速に発展してきた。有限要素法は Rayleigh-Ritz の方法と等価なエネルギー法 の一種であり，このう法によりラプラスの方程式の近似解が求まることが知られている1。また有限要素法によ る解の䈌密解への収束については变分法の原理により数学的に証明されている。

* 大阪大学工学部

** 川崎重工業株式会社技術研究所 
本報では物体が自由表面记もつ流体中で振動する場合の 2 次元の付加質量の問題を有限要素法によつて取り扱 いまず有限要素法による結果と他の方法による結果との比較を行なつて有限要素法の精度を碓かめた。つぎに 矩形断面に対して付加質量係数括よび付加慣性モーメント係数を求めるとともに，付加質量拉よび付加慣性モ一 メントに及ぼす制限水の影響物よび Bilge Keel の影響を調べた。

\section{2 基礎方程式および境界条件}

物体が流体中で運動する場合の付加質量の計算法として次の 2 つの法が考学られる。1つは物体が流体中で 運動しているときの流体の運動エネルギーを求め, これと付加質量が真空中で物体と同じ速度で運動していると きの運動エネルギーが等しいと仮定して付加質量を求める方法である。この方法による付加質量は運動エネルギ 一に上り定義される付加質量である2)。船体振動の付加質量の問題の大部分は上の方法によつて求められてい る3(4)5)。る51つは物体が流体中を運動するときの物体に作用する加速度抵抗を求め, 加速度に比例した抵抗の 此例定数として付加質量を定める方法である。この方法によつて求まる付加質量は慣性力により定義される付加

質量である2)。本報では後者の計算法に上り付加犋量を求める。

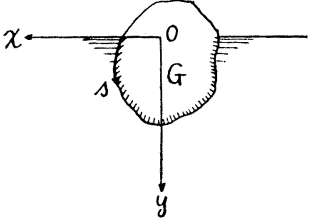

図 1

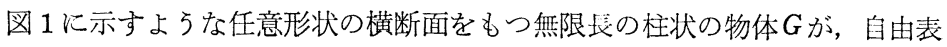
面をもつ完全流体中で周期的な運動を行な5ものとし, 問題を 2 次元として取 り扱う。自由表面上の任意の点を原点とし水平方向に $x$ 軸, 垂直方向に $y$ 軸を とれば, 速度ポテンシャル

$$
\nabla^{2} \phi=0
$$

および境界条件

$$
\text { 自由表面 }(y=0) \text { に和いて } \frac{\partial^{2} \phi}{\partial t^{2}}+g \frac{\partial \phi}{\partial y}=0
$$

物体の表面に捈いて

$$
\frac{\partial \phi}{\partial n}=v_{n}
$$

を満足する。ただし（2）の $t$ は時間， $g$ は重力の加速度，（3）の $n$ は物体の表面に拈いて处向きに立てた法 線， $v_{n}$ は物体の表面の法線方向の速度である。一方流体中の圧力 $p$ （変動圧力）と速度ポテンシャル は次の関係がある。

$$
p=-\rho \frac{\partial \phi}{\partial t}
$$

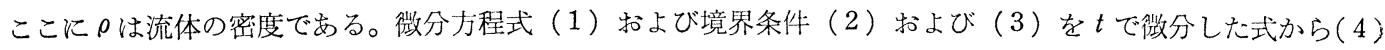

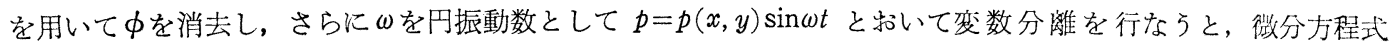
(1) は

$$
\nabla^{2} p=0
$$

また境界条件（2）拉よび（3）はそれぞれ

自由表面 $(y=0)$ に物いて $\quad \frac{\partial p}{\partial y}-\alpha p=0$

物体の表面において

$$
\frac{\partial p}{\partial n}+q=0
$$

となる。ここに

$$
\alpha=\frac{\omega^{2}}{g}, \quad q=\rho \frac{\partial v_{n}}{\partial t}
$$

船体振動のように振動数が大さい場合には自由表面における境界条件は次のようになる。

$$
\text { 自由表面 }(y=0) \text { に扮いて } \quad p=0
$$

（5）拈よび（6)，（7）はダムの動水圧の問題を解く場合に使用される基礎方程式扣よび境界条件でする6)。 
本報ではこれらの式を基䃈方程式执よび境界条件として圧力かの解を求め付加質量を計算する。

\section{3 有限要素法による解法}

境界条件（6）拉上び（7）の一般化した形として

$$
\frac{\partial p}{\partial n}-\alpha p+q=0
$$

を考克，この境界条件の下に微分力程式（5）の近似解を求める。な扮（10）に批いて $q=0, n=y$ とすれば

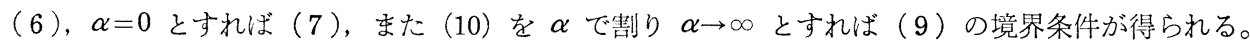

い李次の上うな䅡分 $I(p)$ を考觉る。

$$
I(p)=\iint \frac{1}{2}\left\{\left(\frac{\partial p}{\partial x}\right)^{2}+\left(\frac{\partial p}{\partial y}\right)^{2}\right\} d x d y+\int_{c} q p d s-\int_{c} \frac{1}{2} \alpha p^{2} d s
$$

ここにsは境界に沼つてとつた座標であり, 積分記号 $\int_{c}$ の添字 $c$ は境界に沿つて積分することを示す。変分法 によれば，(11）の積分Iの值を最小にするpは境界条件（10）を満足する微分方程式（5）の解となる。逆に境 界条件（10）を满是する微分方程式（5）の解は（11）の積分Ｉの值を最小にする。したがつて Rayleigh-Ritz の方法によつて微分方程式（5）の近似解を求めることが

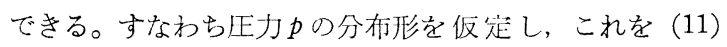
に代入して積分 $I$ の值が最小になるように中を定的ると微 分方程式 (5) の近似解が得られる。

図 2 亿示すような有限の拡がりをもつ流体の領域を考 之, 領域を有限個の三危形要素に分割する。接点の総数を $N$ とし, 接点に $1,2, \cdots, N$ の番号を付け, 各接点に括け る圧力の值を $p_{1}, p_{2}, \cdots, p_{N}$ とし, 各接点に対応した関数 を $f_{1}(x, y), f_{2}(x, y), \cdots, f_{N}(x, y)$ とする。任意の点の压 力かが

$$
p=\sum_{i=1}^{N} p_{i} f_{i}(x, y)
$$

であると仮定し，(12）を（11）に代入して $\partial I / \hat{o} p_{i}=0$ と

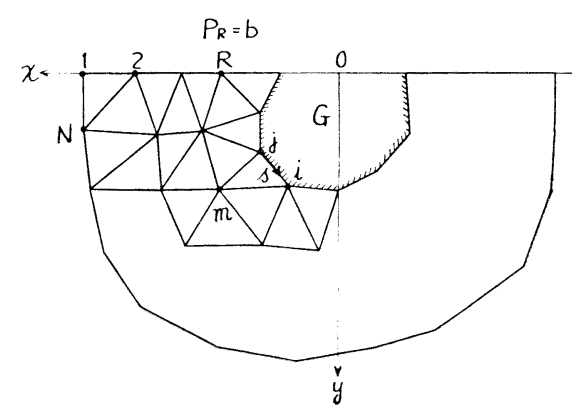

特けば， $p_{i}$ に関する $N$ 元 1 次連立代数方程式が得られる。

$$
\mathbf{A p}=\mathbf{d}
$$

ここに

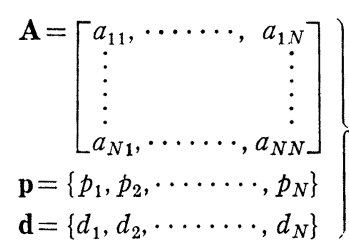

ただし

$$
\left.\begin{array}{rl}
a_{i j} & =k_{i j}-h_{i j} \\
k_{i j} & =\iint\left(\frac{\partial f_{i}}{\partial x} \cdot \frac{\partial f_{j}}{\partial x}+\frac{\partial f_{i}}{\partial y} \cdot \frac{\partial f_{j}}{\partial y}\right) d x d y \\
h_{i j} & =\int_{c} \alpha f_{i} f_{j} d s \\
d_{i} & =\int_{c} q f_{i} d s
\end{array}\right\}
$$

(15) より $k_{\imath j}=k_{j i}, h_{i j}=h_{j i}$ であるから $a_{i j}=a_{j i}$ となり（14）で与兄られる行列 $\mathbf{A}$ は対称行列であることが わかる。

行列 $\mathbf{A}$ 特よびベクトル $\mathbf{d}$ の成分を求める。図 2 に示した三角形要素のうちの 1 つの三角形要素 $i j m$ につ いて考学る。三角形要素内で圧力 $p$ が直線的に変化するものと仮定し, 接点 $i, j, m$ に掠ける压力 $p$ の值をそれ 
ぞれ $p_{i}, p_{j}, p_{m}$ 接点の座標を $\left(x_{i}, y_{\imath}\right),\left(x_{j}, y_{j}\right),\left(x_{m}, y_{m}\right)$ とすれば, 圧力pは次のようになる。

$$
p=p_{i} f_{i}(x, y)+p_{j} f_{j}(x, y)+p_{m} f_{m}(x, y)
$$

ここに

$$
\begin{aligned}
f_{i} & =\left(a_{i}+b_{i} x+c_{i} y\right) / 2 \Delta \\
f_{j} & =\left(a_{j}+b_{j} x+c_{j} y\right) / 2 \Delta \\
f_{m} & =\left(a_{m}+b_{m} x+c_{m} y\right) / 2 \Delta \\
a_{i} & =x_{j} y_{m}-x_{m} y_{j}, \quad b_{i}=y_{j}-y_{m}, \quad c_{i}=x_{m}-x_{j} \\
a_{j} & =x_{m} y_{i}-x_{i} y_{m}, \quad b_{j}=y_{m}-y_{i}, \quad c_{j}=x_{i}-x_{m} \\
a_{m} & =x_{i} y_{j}-x_{j} y_{i}, \quad b_{m}=y_{i}-y_{j}, \quad c_{m}=x_{j}-x_{i} \\
2 \Delta & =x_{i} y_{j}+x_{j} y_{m}+x_{m} y_{i}-x_{j} y_{i}-x_{m} y_{j}-x_{i} y_{m}
\end{aligned}
$$

まず $k_{i j}$ を求める。三角形要素 $i j m$ についての $k_{i j}$ を $k_{i j}$ と書き，(15）の $k_{i j}$ の式に (17) の $f_{i}, f_{j}$ を代入し積分して $k^{e} i$ を求めると

$$
k^{e}{ }_{i j}=\left(b_{i} b_{j}+c_{i} c_{j}\right) / 4 \Delta
$$

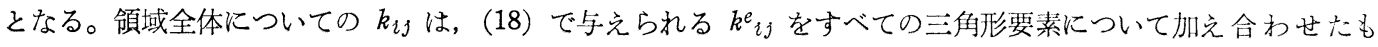
のであるから

$$
k_{i j}=\sum^{R} k_{i j}
$$

となる。な怙 $\sum^{R}$ は全領域について加え合わせることを示す。

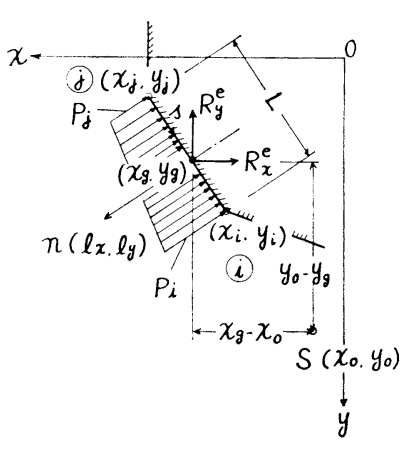

図 3

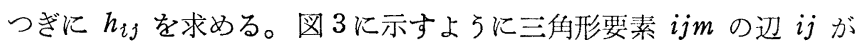
境界の一部になつている場合を考光, 辺 $i j$ の長さを $L$ とし, $j$ 点を原 点とし座標 $s$ を辺 $i j$ に一致させてとる。压力 $p$ は三角形要素内で直線 的に変化すると仮定したから, 辺 $i j$ 上では

$$
p=p_{i} \frac{s}{L}+p_{j}\left(1-\frac{s}{L}\right)
$$

となり，(17）の $f_{\imath}$ 抢よび $f_{\jmath}$ は

$$
\left.\begin{array}{l}
f_{i}=s / L \\
f_{j}=1-s / L
\end{array}\right\}
$$

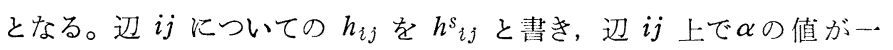
定であるものとすれば, $h^{s_{i j}}$ は (15) の $h_{i j}$ の式に (21) を代入する ことにより

$$
h^{s}= \begin{cases}\frac{1}{6} \alpha L & (i \neq j) \\ \frac{1}{3} \alpha L & (i=j)\end{cases}
$$

で与えられる。また領域全体についての $h_{i j}$ は境界上のすべての辺について加え合わせたものであるから

$$
h_{i j}=\sum^{B} h^{s}{ }_{i j}
$$

となる。な拉 $\sum^{B}$ は境界上のすべての辺について加え合わせることを示す。

つぎに $d_{i}$ を求める。いま辺 $i j$ 上で $q$ の值が直線的に变るものとし， $i$ 点拉よび $j$ 点に抢ける $q$ の值をそれ ぞれ $q_{i}$ 抢よび $q_{j}$ とすれば, $q$ は压力 $p$ の式 $(20)$ と同形となり

$$
q=q_{i} \frac{s}{L}+q_{j}\left(1-\frac{s}{L}\right)
$$

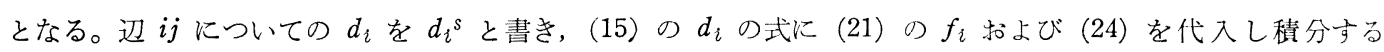
と $d_{i} s$ は

$$
d_{i}^{s}=-\frac{1}{6}\left(2 q_{i}+q_{j}\right) L
$$

となる。領域全体についてのdi は次式で与えられる。 


$$
d_{i}=\sum^{B} d_{i}^{s}
$$

$a_{i j}$ は (19) 拈よび (23) を(15) の $a_{\imath j}$ の式代入すると求まり， $d_{\imath}$ は (26) で与えられるから，(13）の $n$ 元 1 次連立代数方程式の係数拉よび定数項が求をる。(13) の方程式を解けば接点 $i$ に扣ける圧力 $p_{i}$ が求ま るのであるが，境界条件として压力 $p$ の值が与えられている場合には（13）の方程式に対して次のょうな変形を 行なら必要がある。たと竞ば図 2 の $R$ 点が $p=b$ の境界上にある場合を考觉ると，(13）の $R$ 番目の方程式

$$
\sum_{j=1}^{N} a_{R j} p_{j}=d_{R}
$$

の代わりに

$$
p_{R}=b
$$

を用いなければならない。したがつて行列 $\mathbf{A}$ の成分 $a_{R j}(j=1,2, \cdots, N)$ を

$$
a_{R j}= \begin{cases}1 & (j=R) \\ 0 & (j \neq R)\end{cases}
$$

と拈きまたベクトル $\mathbf{d} の R$ 番目の成分 $d_{R}$ を

$$
d_{R}=b
$$

とする必要がある。

接点 $i$ 飞招ける圧力 $p_{i}$ は方程式 (13) の解として

$$
\mathbf{p}=\mathbf{A}^{-1} \mathbf{d}
$$

で与兄られる。流体中の任意の点の圧力 $p$ は（16）によつて計算できる。この压力 $p$ を物体の全表面について積 分すれば物体に作用する加速度抵抗が求まる。 $x$ 方向拉よび $y$ 方向の単位長さ当りの加速度抵抗 $R_{x}$ 抽よび $R_{y}$ 屿次式で与えられる。

$$
\left.\begin{array}{l}
R_{x}=\int p l_{x} d s \\
R_{y}=\int p l_{y} d s
\end{array}\right\}
$$

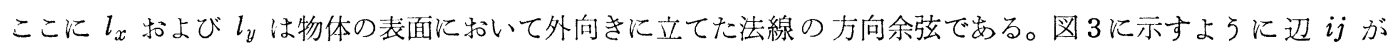
物体の表面上飞ある場合を考党, 辺 $i j$ に作用する $x$ 方向捛よび $y$ 方向の加速度抵抗 $R_{x}{ }^{e}$ 拉よび $R_{y}{ }^{e}$ を求め る。辺 $i j$ に括いて外向きに立てた法線の方向余弦 $l_{x}, l_{y}$ は

$$
\left.\begin{array}{l}
l_{x}=\left(y_{i}-y_{j}\right) / L \\
l_{3}=\left(x_{j}-x_{i}\right) / L
\end{array}\right\}
$$

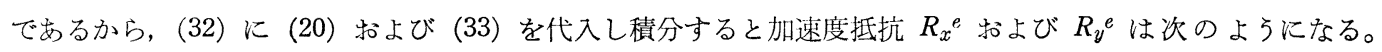

$$
\left.\begin{array}{l}
R_{x}^{e}=\frac{1}{2}\left(p_{i}+p_{j}\right)\left(y_{i}-y_{j}\right) \\
R_{y}^{e}=\frac{1}{2}\left(p_{i}+p_{j}\right)\left(x_{j}-x_{i}\right)
\end{array}\right\}
$$

物体汇作用する $x$ 方向拈上び $y$ 方向の加速度抵抗 $R_{x}$ 招上び $R_{y}$ は, (34) で与兄られる加速度抵抗 $R_{x}{ }^{e}$ 扣よ び $R_{y}{ }^{e}$ を物体の全表面について加光合わせたものであるから

$$
\left.\begin{array}{l}
R_{x}=\sum^{G} R_{x}{ }^{e} \\
R_{y}=\sum^{G} \cdot R_{y}^{e}
\end{array}\right\}
$$

で与兄られる。な拉 (35) の $\sum^{G}$ は物体の全表面について加兄合わせることを示す。付加質量は加速度に比例し た抵抗の比例定数であると定義すれば， $x$ 方向（水平方向）拈よび $y$ 方向（垂直方向）の付加質量 $m_{H}$ 打よび $m_{V}$ はそれぞれ次式で与えられる。

$$
\left.\begin{array}{l}
m_{H}=R_{x} / \dot{U} \\
m_{V}=R_{\dot{\imath} /} / \dot{V}
\end{array}\right\}
$$

ここに $\dot{U}$ 扣よび $\dot{V}$ は $x$ 方向拉よび $y$ 方向の加速度である。

以上で水平方向扣上び重直方向の付加質量 $m_{H}$ 拈よび $m_{V}$ が求まつた。物体が流体中で回転運動していると きの付加慣性モーメント $I_{a}$ も付加質量の場合と同様にして求めることができる。回転運動の回転中心 $S$ の座標 
を $\left(x_{0}, y_{0}\right)$ とし, 辺 $i j$ に作用する加速度抵抗化よる回転中心 $S$ まわりの抵抗モーメント $M^{e}{ }_{R}$ を求める。回転

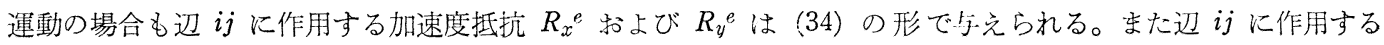
圧力 $p$ の圧力中心の座標 $\left(x_{g}, y_{g}\right)$ は

$$
\left.\begin{array}{l}
x_{g}=x_{i}+\frac{1}{3}\left(x_{j}-x_{i}\right) \frac{p_{i}+2 p_{j}}{p_{i}+p_{j}} \\
y_{g}=y_{i}+\frac{1}{3}\left(y_{j}-y_{i}\right) \frac{p_{i}+2 p_{j}}{p_{i}+p_{j}}
\end{array}\right\}
$$

となる。加速度抵抗 $R_{x} e$ および $R_{y}{ }^{e}$ は圧力中心 $\left(x_{g}, y_{g}\right)$ に作用すると考光ると，回転中心 $S$ まわりの抵抗モ ーメント $M_{R^{e}}$ は, 図3を参照して

$$
M_{R}{ }^{e}=R_{x}{ }^{e}\left(y_{0}-y_{g}\right)+R_{y}^{e}\left(x_{g}-x_{0}\right)
$$

となる。物体に作用する回転中心 $S$ まわりの全抵抗モーメント $M_{R}$ は, (38)で与えられる抵抗モーメント $M_{R}{ }^{e}$ を物体の全表面について加え合わせたものであるから

$$
M_{R}=\sum^{G} M_{R}{ }^{e}
$$

となる。付加慣性モーメントを角加速度に比例した抵抗モーメントの比例定数として定義すれば, 付加慣性モー メント $I_{a}$ は次式で与兄られ。

$$
I_{a}=M_{R} / \ddot{\theta}
$$

ここに $\ddot{\theta}$ は物体の回転中心 $S$ まわりの角加速度である。

\section{4 有限要素法による計算值の精度の検討}

前項の理論計算に基づいて垂直振動の付加質量係数 $C_{V}$, 水平振動の付加質量倸数 $C_{H}$ 拈よび捩り振動の付加 慣性モーメント係数 $C_{T}$ を求める電子計算機プログラムを作成した。本プログラムで計算される付加質量係数 $C_{V}, C_{H}$ および付加慣性モーメント係数 $C_{T}$ は次式で定義されるもので両る。

$$
\left.\begin{array}{c}
m_{V}=\frac{1}{2} C_{V} \rho \pi b^{2} \\
m_{H}=\frac{1}{2} C_{H} \rho \pi d^{2} \\
I_{a}=C_{T} \rho \pi d^{4}
\end{array}\right\}
$$

ここにbは物体の横断面の半幅, $d$ は契水である。本プログラムでは任意の形状の横断面をもつ物体が任意の形 状の境界をもつ流体中で振動する場合の付加質量係数扰よび付加慣性モーメント係数を求めることができる。な 㧧体の自由表面の条件として（9）の条件を用い，数值計算に際しては電子計算機 Facom 230-50を使用し た。

半径 $r$ の円断面㧍よび半幅 $b$ の矩形断面をもつ無限長の一様断面棒が流体中でそれぞれ契水 $r$ および $d$ の状態 で垂直振動，水平振動拈よび㨝り振動するときの付加質量係数扣よび付加慣性モーメント係数を上記の電子計算 機プログラムにより計算した。有限要素法では流体の領域を無限大にとることができないので，付加質量に及涪

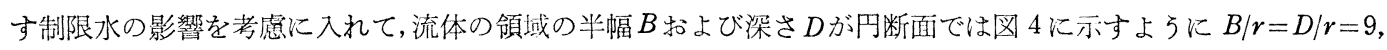

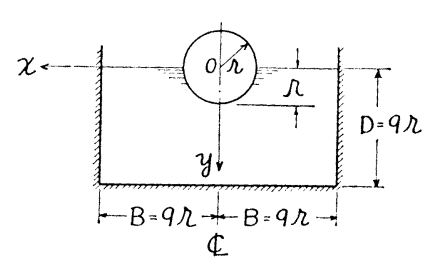

図 4
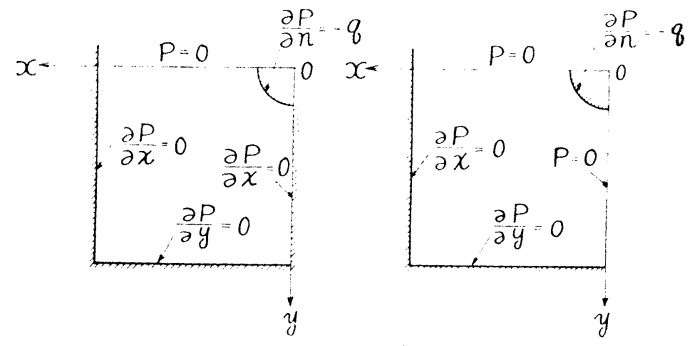

(a) 垂直振動

（b）水平振動掞よび㧪り振動 
矩形断面では $B / b=D / d=7.5$ である矩形領域を考光, 棒が自由表面の中央にあるものとした。この計算例では 流体の領域は左右対称で岕るので左半分または右半分の領域を考劣ればよい。図 4 に示した円断面の場合につい て垂直振動，水平振動括よび颃り振動に対する境界条件を示せば図５の上らになる。ここで注意すべき点は垂直 振動では压力分布が左右対称となるため対称軸（ $y$ 軸）上で $\partial p / \partial x=0$ となるのに対して，水平振動拉よび㨝り

表 1 有限要素法による結果と厳密解の

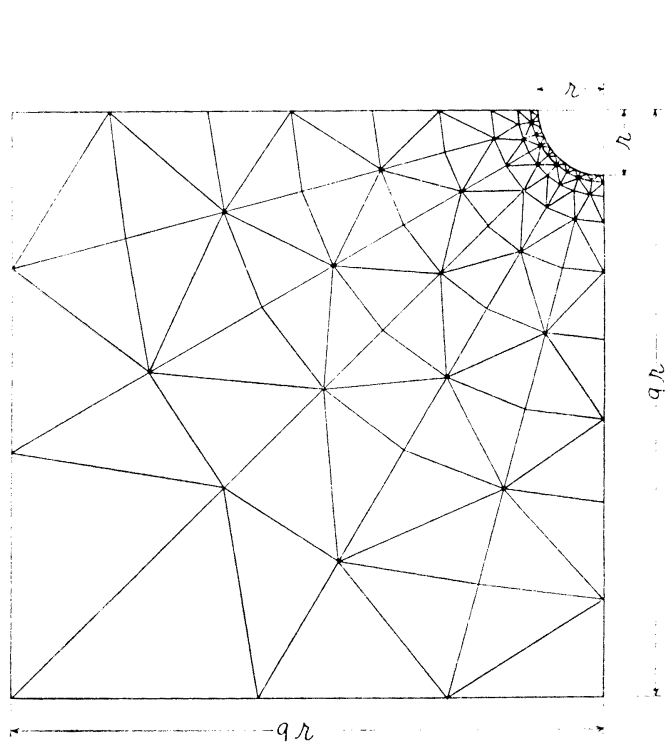

図 6 領域の分割 (円断面の場合) 按点の数 $=88$ 三角形要素の数 $=132$

\begin{tabular}{|c|c|c|c|c|c|c|}
\hline & & $C_{V}$ & \multicolumn{2}{|c|}{$C_{H}$} & $C_{T}{ }^{*}$ & 佯 \\
\hline \multicolumn{2}{|c|}{ 有限要素法 } & 0.967 & \multicolumn{2}{|c|}{0.368} & 0.0460 & $B / r=D / r=9$ \\
\hline \multicolumn{2}{|c|}{ 厳 密 解 } & 1.000 & \multicolumn{2}{|c|}{0.405} & 0.0507 & $B / r=D / r=\infty$ \\
\hline \multicolumn{2}{|c|}{$\frac{\text { 有限要素法 }}{\text { 厳密解 }}$} & 0.967 & \multicolumn{2}{|c|}{0.905} & 0.907 & \multirow[b]{2}{*}{ のときの値であ } \\
\hline \multicolumn{6}{|c|}{$\begin{array}{l}* \text { 付加慣性モーメント係数 } C_{T} \text { は } y_{0} / d=0.5 \\
\text { る。 }\end{array}$} & \\
\hline \multicolumn{2}{|c|}{ 表 2} & \multicolumn{5}{|c|}{$\begin{array}{l}\text { 有限要素法による結果と他の方法に } \\
\text { よる結果の比較一矩形断面 }\end{array}$} \\
\hline \multirow{4}{*}{$C_{V}$} & \multicolumn{2}{|l|}{$d / b$} & 0.5 & 1.0 & 1.5 & 備 \\
\hline & \multicolumn{2}{|c|}{ 有限要素法 } & 1.30 & 1.48 & 1.61 & $D / d=B / b=7.5$ \\
\hline & \multicolumn{2}{|c|}{ Lewis } & 1.36 & 1.51 & 1.62 & \multirow{2}{*}{$D / d=B / b=\infty$} \\
\hline & \multicolumn{2}{|l|}{ Koch } & 1.42 & 1.65 & 1.78 & \\
\hline \multicolumn{3}{|c|}{$C_{V}$ finite $/ C_{V}$ Lewis } & 0.956 & 0.980 & 0.994 & \\
\hline & 有限 & 满素法 & 0.462 & 0.445 & 0.435 & $D / d=B / b=7.5$ \\
\hline$C_{H}$ & Land & weber & 0.502 & 0.463 & 0.441 & $D / d=B / b=\infty$ \\
\hline & Koch & & 0.487 & 0.478 & 0.470 & \\
\hline$C_{H} \mathrm{fin}_{C_{I}}$ & $\begin{array}{l}\text { nite/ } \\
H \text { Land }\end{array}$ & weber & 0.920 & 0.961 & 0.986 & \\
\hline
\end{tabular}

振動（颃り中心が $y$ 軸上にあるとき）では，圧力分布が左右逆対称となるため，対称軸（ $y$ 軸）上で $p=0$ とな ることである。領域の分割は，正力分布の变化を考虑して，図6に示す上5に物体の表面近くで細かく，物体か ら遠ざかるにつれて粗くした。掞点の数は円断面の場合乱よび矩形断面の場合ともに 88, 三角形要素の数は円 断面の場合 132 , 矩形断面の場合 130 でめる。

上記の例についての計算結果を他の方法による結果と比較して表 1 拈よび表 2 に示す。表 1 は円断面に対する 付加質量係数 $C_{V}, C_{H}$ 抢よび付加慣性モーメント係数 $C_{T}$ について, 有限要素法による值と厳密解を比較した ものである。表 2 は矩形断面に対する付加質量倸数 $C_{V}$ 抢よび $C_{H}$ について, 有限要素法による值と他の方法 による値を比較したものである。表 2 の Lewis と記した欄の $C_{V}$ の值は F. M. Lewis ${ }^{3)}$ が解析的な方法によつ て求めた值であり, Koch と記した欄の $C_{V}$ 扤よび $C_{H}$ の值は J.J.Koch7) が method of electrical analogy によつて求めた值である。な怙 Koch の值は Todd の „Ship Hull Vibration”8): p.84 より抜萃したものであ る。また Landweber と記した欄の $C_{H}$ の值 L. Landweber, M.C.de Macagno4) が Lewis form 亿対して求 めた $C_{H}$ の計算式を用いて, 断面積比 $\sigma=1$ として求めた計算值である。表 2 の第 5 番目の欄の值は有限要素 法淿るる $C_{V}$ の值と Lewis の $C_{V}$ の值の比, また第 9 番目の欄の值は有限要素法による $C_{H}$ の值と Landweber の $C_{H}$ の值の比である。

表 1 就よび表 2 上り次のことがわかる。有限要素法による計算値は垂直振動については正解に対して最大 $4 \%$ 程度の誤差がありかなり精度がよいのに対して, 円断面の場合の水平振動括よび掘り振動については最大約 10 \%の誤差がありあまり精度がよくない。ま水平振動の付加質量の大きさ扣よび㨝り振動の付加慣性モーメント の大きさが船体自身の質量の大きさ扣よび質量慣性モーメントの大きさと同程度であるとすれば，有限要素法に より求めた付加質量抢よび付加慣性モーメントを用いて固有振動数を求めると, 全質量拉よび全質量慣性モーメ ントを $5 \%$ 低く見積ることになるから固有振動数は $2.5 \%$ 高く見積り過ぎることになる。しかし一般に水平振動 の付加質量㧍よび㨝り振動の付加慣性モーメントの全質量招よび全質量慣性モーメントに占める割合は上述の場 
一合よりかなり小さいと考えられるので，実用上は有限要素法による計算值は十分な精度があるものと考兄られ る。表 2 より一般に正解に比べて Koch の值は高く，有限要素法による值は低くなつていることがわかる。有 泿要素法による值が正解より低いのは，この方法固有の性質によるものである 1)。

有限要素法による計算結果の一例を図 7 および図 8 亿示す。図 7 は綎軸に $C_{I I}$, 横軸沉 b/d をとり矩形断面

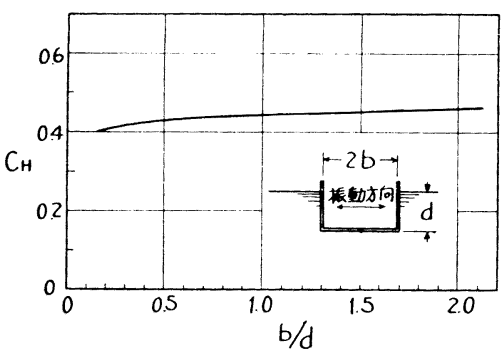

図 7 矩形断面に対する水平振動の 付加質量係数 $C_{H}$

汇対する水平振動の付加質量係数 $C_{H}$ を示したものである。 図8 は縦軸比 $C_{T}$, 横軸飞 $y_{0} / d$ をとり, b/d の值をパラメー ターとして，矩形断面に対する付加慣性モーメント係数 $C_{T}$ を 示したものである。な抢次項で述べるように $B / b \geq 7, D / d \geq 7$ であれば，付加質量抢よび付加慣性モーメントに及涪す制限水 の影響は無視できるから， $D / d=B / b=9$ として求めた図 7 の $C_{H}$ 抢よび図 8 の $C_{T}$ は流体の領域が無限と考光たときの值と してよい。

\section{5 付加質量および付加慣性モーメントに及ばす制限水の影響 および Bilge Keel の影響}

船体振動の付加質量および付加慣性モーメントに及ぼす制限水の影響は浅水影響抽よび側壁の影響の 2 つ大 别される。浅水影響については富田 ${ }^{9)}$, Prohaska ${ }^{10)}$ の模型実験に上る研究（垂直振動), Koch ${ }^{7}$ ) の method of electrical analogy に上る研究 (垂直振動, 水平振動), 吉識11), Havelock ${ }^{12}$ ) の理論的な研究（垂直振動, 水 平振動）等があり，側壁の影響については吉識11）の理論的な研究（垂直振動，水平振動）がある。また付加質 量扣よび付加慣性モーメントル及ぼす Bilge Keel の影響については Wendel ${ }^{13)}$ (垂直振動), 渡辺 ${ }^{14)}$ (横動摇)

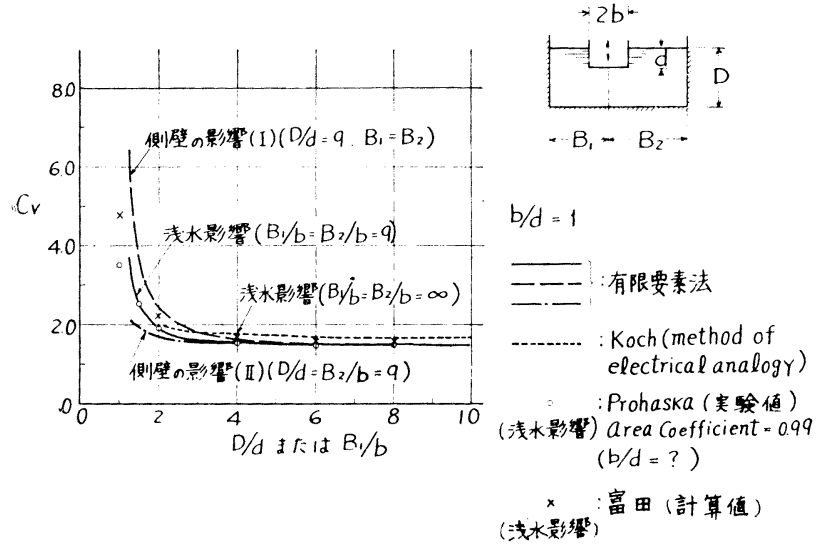

因 9 垂直振動の付加質量汇及汴す制限水の影響
等の研究がある。

本報では $b / d=1$ の炬形断面につい て垂直振動扣よび水平振動の付加質量 係数 $C_{V}, C_{H}$ 呿上び㨝り振動の付加慣 性モーメント係数 $C_{T}$ を有限要素法汇 上つて求め, 付加質量拉上び付加慣性 モーメントに及活す制限水の影響拈上 び Bilge Keel の影響を調べた。

垂直振動，水平振動の付加質量打上 び㹉り振動の付加慣性モーメントに及 汸す制限水の影響沉ついての結果を， 縦軸汇付加質量係数 $C_{V}$ または $C_{H}$ または付加慣性モーメント係数 $C_{T}$ : 横軸に浅水影響の場合は $D / d$, 側壁 の影響の場合は $B_{1} / b$ をとり図 9 , 図 
10 および咸 11 に示す。戍 9, 図 10 および成 11 の策線，破線拈よ び一点鎖線はすべて有限装素法に よる計算值であつて，それ文れ浅 水影響，丽側に壁があるときの側 壁の影響拉よび片側に壁があると さの側壁の影響を示す。威 9 およ び戍 10 の点線は Koch が method of electrical analogy によ つて求めた值であつて浅水影響を 示す。図9の×印は富田が模型策 験結果に基づいて求めた付加澌量 增加の実験式に叔いて $\beta=1$ ( $\beta$ は Area-Coefficient), $b / h=2^{*}(b, h$ は富田の論文中で使われている記 号であつてそれぞれ稯断面の幅拉 よび契水を示す）として付加質量 の増加率 $c$ を求め, 無限深さにお ける付加質量係数 $C_{V \infty}$ とし

$$
C_{V}=C_{V_{\infty}}(1+c)
$$

の計算式により求めた有限深さに む壮る付加質量係数 $C_{V}$ の值を 示す。また网 9 には Prohaskaが 獏型実験によつて浅水影響を調べ
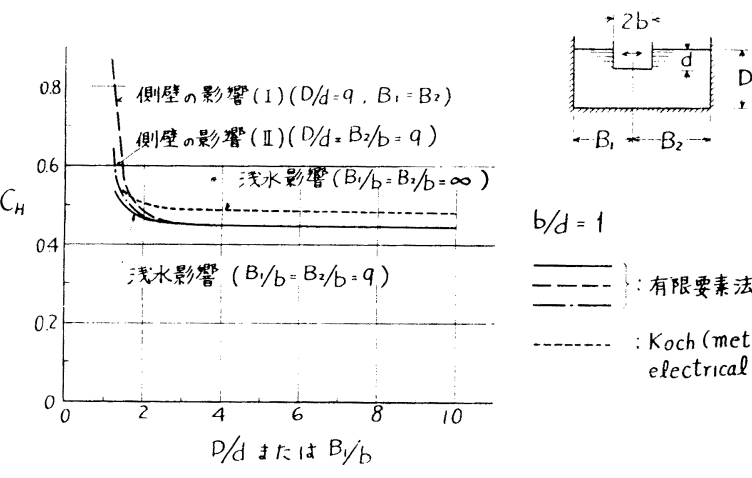

$+B_{1}=B_{2}-$

$b / d=1$

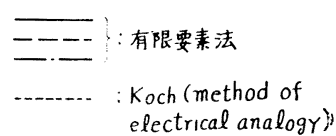

四 10 水平振動の付加質量に及ぼす制限水の影響

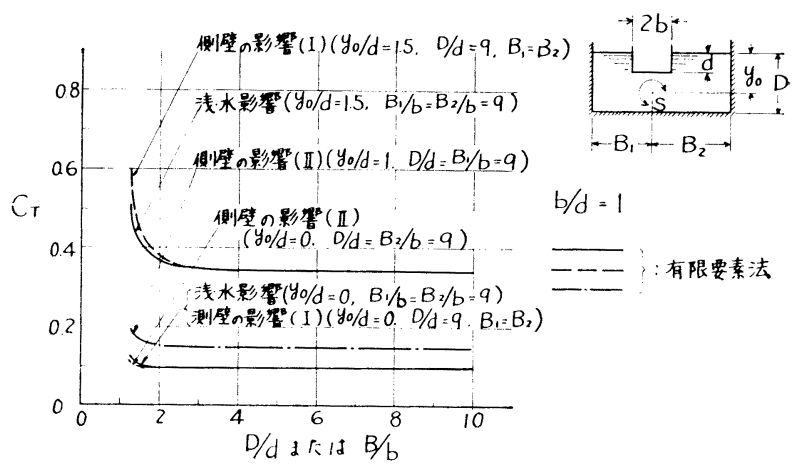

図 11 据り振動の付加慣性モーメントに及添す制限水の影響

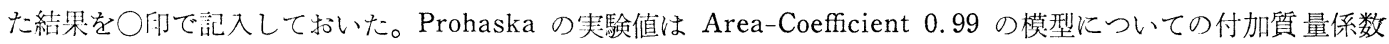
$C_{V}$ であるが b/d の值が不明である。なお Prohaska の実験值は Todd の “Ship Hull Vibration”8), p. 80, Fig 24 の曲線から值を読みとりプロットしたものである。

Prohaska の実験值は b/d の值が不明であるので，図 9 に拈いて○印の值と実線の值を直接比較することはで きないが，两者の傾问はよく一致している。また図 9 に拈いて×印の值と実線の值を比較すると印の値の方が わずかに大さくなつている。眓 9 に拈いて実線, 破線, 一点鎖線の 3 つる比べると, 垂直振動の付加質量に及ぼ す制限水の影響の大きさは屾側に壁があるときの側壁の影響, 浅水影響, 片側に壁があるときの側壁の影響の順 になつている。図 9 より重值振動では $D / d \geq 7, B_{1} / b \geq 7$ 以上であれば付加質量に及法す制限水の影響は無視で きることがわかる。

重直振動の付加賀量に及ぼす浅水影響について有限要素法による結果と他の方法による結果を, 有限深さに打 ける付加質量係数 $C_{V}$ と無限深さに扣壮付加質量係数 $C_{V \infty}$ の比の形で比較して表 3 に示す。表 3 の有限要素 法, Koch, 舅田の値は矩形断面 $(b / d=1)$, Prohaska の值は Area-Coefficient 0.99 の矩形断面に近い横断面.

表 3 垂直振動の付加質量に及ぼす浅水影響（有限要素法による 結果と他の方法による結果の比較)

\begin{tabular}{|c|c|c|c|c|c|c|c|c|}
\hline & $D / d$ & 1.25 & 1.5 & 2.0 & 3.0 & 5.0 & $\infty$ & 储 \\
\hline & 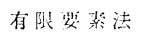 & 2.54 & 1.73 & 1.43 & 1.11 & 1.02 & 1.0 & 矩形断面 $(b / d=1)$ \\
\hline \multirow{4}{*}{$\begin{array}{c}C_{V} \\
C_{V}-\infty\end{array}$} & Koch & 2.33 & 1.64 & 1.22 & 1.08 & 1.04 & 1.0 & 矩形断面 $(b / d=1)$ \\
\hline & Prohaska & 2.06 & 1.79 & 1.36 & 1.16 & 1.05 & 1.0 & 矩形に近い断面* \\
\hline & 苦棓靖 外 & 1.59 & 1.40 & 1.24 & 1.10 & 1.06 & 1.0 & 円断面 \\
\hline & nt & 2.35 & 1.90 & 1.48 & 1.20 & 1.06 & 1.0 & 知形断面 $(b / d=1)$ \\
\hline
\end{tabular}

* Area Coefficient $=0.99, b / d$ の值は不明である 
吉識外の值は円断面に対するものである。表 3 亿扮いて有限要素法, Koch, Prohaska 拈よび富田の 4 つの值を 比較すると 4 つの值は，かなり上く一致していることがわかる。吉識の值が他の 4 つの值とかなり異なつている のは円断面と矩形断面のちがいによるものである。

図 10 より次のことがわかる。水平振動の付加質量に及洔す制限水の影響は, 洞側に壁があるとさの側壁の影 響, 片側に壁があるときの側壁の影響, 浅水影響の順に小さくなつている。また水平振動では $D / d \geq 4, \quad B_{1} / b \geq 4$ であれば付加質量に及ぼす制限水の影響は無視できる。

図 11 では, $y_{0} / d=0,1.0,1.5$ の場合の $C_{T}$ の值が示してある。同図より据り振動の付加慣性モーメントに 及ぼす制限水の影響は㨝り中心の位置によつてかなり左右されることがわかる。また挍り振動では $D / d \geq 4$, $B_{1} / b \geq 4$ であれば付加慣性モーメントに及ぼす制限水の影響は無視できる。

図 9, 図 10, 図 11 の 3 つを比べると, 付加質量特よび付加慣性モーメントに及ぼす制限水の影響は, 垂直 振動がもつとも大きく，水平振動と㨝り振動が同程度か水平振動が少し大きい程度であることがわかる。

$B / d=1$ の矩形断面に水平と $45^{\circ}$ の角度で Bilge Keel がついている場合について, Bilge Keel の長さ $k$ を

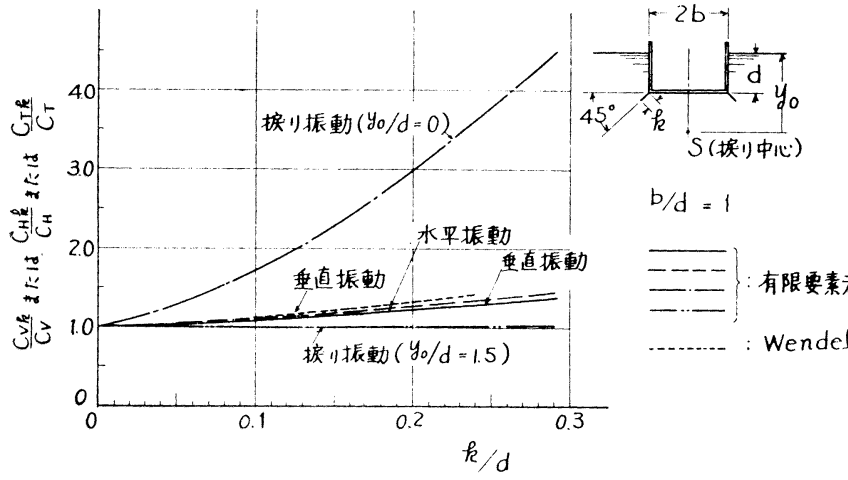

図 12 付加質量および付加慣性モーメント に及ぼす Bilge Keel の影響

变えて付加質量係数拈よび付加慣 性モーメント係数を求め, 振動の 付加質量拉よび付加慣性モーメン トに及ぼす Bilge Keel の影響を 調べた。その結果を綎軸泣 $C_{V k} /$ $C_{V}$ または $C_{H R} / C_{H}$ または $C_{T k} /$ $C_{T}$ をとり, 横軸に $k / d$ をとつて 図 12 亿示す。 $C_{V k}, C_{H k}$ 怙よび $C_{T k}$ の添字 $k$ は Bilge Keel があ るときの值であることを示す。図 12 の実線, 破線, 一点鎖線扮よ び二点鎖線は有限要素法による計 算值であつて，それぞれ垂直振 動, 水平振動, $y_{0} / d=0$ のときの

掘り振動拉よび $y_{0} / d=1.5$ のときの㨝り振動に対する值であることを示す。また図 12 の点線は Wendel が垂 直振動の付加質量に及活す Bilge Keel の影響を理論的に求めた值である。なおこの值は Todd の “Ship Hull Vibration”8) p.73 より抜萃した。同図より掘り振動の付加慣性モーメントに及ぼす Bilge Keel の影響は㨝り 中心(回転中心) $S$ の位置によつて大きく左右されることがわかる。据り振動では $y_{0} / d=0$ のときの Bilge Keel の影響が大きいのは，㨝り中心が断面の対称軸と水平面との交点の位置にあるため流体が Bilge Keel に直角に

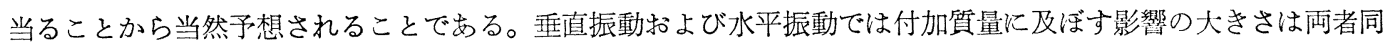
程度で，たとえば $k / d=0.1$ の場合でもその付加質量が Bilge Keel のないときに比べて約 $8 \%$ 增加するに過 ぎない。

渡辺は長さ $\frac{1}{2} L$ ( $L$ は船の全長) の船体中央部に Bilge Keel をもつ船が満载状態 $\left(y_{0} / d=0\right)$ で横動摇して いる場合について付加慣性モーメントを理論的に求めている(14),15) この計算例では Bilge Keel の寸法が不明で あるので有限要素法による結果と比較することはできないが，渡辺の計算結果を用いて $C_{T k} / C_{T}$ の值を計算して みると次のようになる。Bilge Keel がある場合の船体中央部の付加慣性モーメント $\Delta I_{k}$ は， $\rho$ を流体の密度, $L$ を船の全長, $g$ を重力の加速度， $M$ を scale を表わす定数とすれば

$$
\Delta I_{k}=0.04744 \rho g \pi L M^{4}
$$

また Bilge Keel のない場合の船体中央部の付加慣性モーメント $\Delta I$ は

$$
\Delta I=0.01910 \rho g \pi L M^{4}
$$

となる。 $\Delta I_{k}$ と $\Delta I$ の比をとると $C_{T k} / C_{T}=\Delta I_{k} / \Delta I$ であるから

$$
C_{T k} / C_{T}=2.48
$$

そなる。この結果からも回転中心が水面近くにある $\left(y_{0} / d=0\right)$ ときは, 付加慣性モーメントに及ぼす Bilge Keel 
の影響がかなり大きいことがわかる。

\section{6 結 言}

物体が自由表面をもつ流体中で振動する場合の付加質量係数および付加慣性モーメント係数を有限要素法によ つて求め，その計算值が尘用上十分な精度をもつことを確かめるとともに，付加質量执よび付加慣性モーメント に及济す制限水の影響拉よび Bilge Keel の影響を調べた。その結果次の結論が得られた。

（1）付加質量怙よび付加慣性モーメントに及ぼす制限水の影響は垂直振動，水平振動，掘り振動の順に大き く, 垂直振動では $D / d \geq 7, B_{1} / b \geq 7$, 水平振動および掘り振動では $D / d \geq 4, B_{1} / b \geq 4$ であればこれを 無視することができる。

（2）振り振動の付加慣性モーメントに及ぼす Bilge Keel の影響は据り中心の位置によつて大きく影響され る。

\section{参 考 文 献}

1) O.C.Zienkiewicz, Y.K. Cheung : The Finite Element Method in Structural and Continuum Mechanics, McGraw-Hill, 1967, p. 148 168, p. 219 227

2）元良誠三：見掛貎量に就て，造船協会論文集第 87 号，1955

3) F. M. Lewis: The Inertia of the water Surrounding a Vibrating Ship, Trans. S. N. A. M. E, vol. 37, 1929

4) L. Landweber, M.C. de Macagno : Added Mass of Two-Dimensional Forms Oscillating in a Free Surface, Jour. of Ship Research. No.5. 1957

5）熊井豊二：船体㨝机振動に拈ける付加慣性力率について，造船協会論文集 104 号，1959

6) O.C.Zienkiewicz, B. Nath: Earthquake Hydrodynamic Pressures on Arch Dam-An Electric Analogue Solution, Proc. Inst. C. V. Eng. 1963

7) J.J.Koch : Experimental Method for Determining the Virtual Mass for Vibrations of Ships, T.M.B., Trans. 225. 1949. または Ingenier Archiv. 1933

8) F.H. Todd : Ship Hull Vibration, Edward Arnold L. T., London, 1961, Chapter N p. 65 104.

9）富田哲次郎：船体固有振動数に対する水深影響の一計算法，造船協会論文集第 107 号，1960

10) C. W. Prohaska : The Vertical Vibrations of Ship, Shipbuilder, 1947.または A.T.M.A., 1947

11）吉識雅夫, 山本善之, 佐久間武, 長本良男: 船体振動に括忊る付加質量に関する一考察, 造船協会論文 集第 84 号, 1952

12) Sir. T.H. Havelock : Ship Vibrations-the Virtual Inertia of a Spheroid in Shallow Water, I.N. A. October. 1952

13) K. Wendel : Hydrodynamische Massen und Hydrodynamische Massenträgheitsmomente, S. T. G., 1950

14）渡辺患弘：横動摇に括ける船の見掛の慣性力率に就て，造船協会会報 52 号，1933

15) M. Yoshiki, T.Kumai, T.Kanazawa : Recent Studies on Ship Vibration in Japan, The Society of Naval Architects of Japan, 60 th Aniversary Series, vol.10, 1965, p. 11 13 